\title{
The Distribution of First Lesions in Leprosy
}

\author{
R. J. HOR'TON \\ St Bartholomew's Hospital, London \\ SUSAN POVEY \\ University C'ollege Hospital, I.ondon
}

During 1963 there was some discussion in the columns of Leprosy Review concerning the mode of entry of Mycobacterium leprae into the body (Spickett, I963; Weddell \& Palmer, 1963; Weddell, Palmer \& Recs, r 963). It was suggested that some further work on the sites of first lesions might be of interest. While doing other epidemiological work on leprosy in South India, members of a Cambridge medical expedition were able to collect data about the sites of first lesion in $25^{2}$ cases of leprosy.

The cases included in this study are those in which a clear single first lesion, hypopigmented patch or anaesthetic patch was described in the clinical notes. The results are divided into three groups according to the age at onset of leprosy, information obtained from clinical notes and occasionally by direct questioning of the patient. Bearing in mind that primary infection would have occurred about 5 years before recognisable symptoms appeared, an age of onset of 9 years or less may be regarded as probable infection during infancy, and IO-I 8 years, infection during childhood.

If the distribution of lesions is random, one would expect the distribution of lesions in different parts of the body to be proportional to their surface areas. These have been calculated using the Berkow scale (Berkow, r 924) making allowances for differences in shape at different ages. (Table I.)

TABLE I

\section{Distribution of first lesions according to age}

\begin{tabular}{|c|c|c|c|c|c|c|}
\hline \multirow{3}{*}{$\begin{array}{l}\text { Site of } \\
\text { first } \\
\text { lesion }\end{array}$} & \multicolumn{2}{|c|}{ Adults } & \multicolumn{2}{|c|}{ Children } & \multicolumn{2}{|c|}{ Infanls } \\
\hline & \multicolumn{2}{|c|}{ ( > I 8 years at onset $)$} & \multicolumn{2}{|c|}{$(\mathrm{I} \mathrm{O}-\mathrm{I} 8$ years at onset) } & \multicolumn{2}{|c|}{ ( < Io years at onset } \\
\hline & Expected & Obseried & Expected & Observed & Expected & Observed \\
\hline Head & 12 & 14 & 8 & 6 & 6.5 & 7 \\
\hline $\begin{array}{l}\text { Arms } \mathbb{E}^{2} \text { Hands } \\
\text { Trunk, Buttocks } \mathbb{E}^{2}\end{array}$ & 25 & 42 & I 6 & 24 & 7 & 7 \\
\hline Thighs & 66 & 39 & 43 & $3^{8}$ & I 7 & I 8 \\
\hline Legs Ë Feet & 27 & 35 & I 8 & 17 & $6 \cdot 5$ & 5 \\
\hline Totals & \multicolumn{2}{|c|}{ I 30} & \multicolumn{2}{|c|}{85} & \multicolumn{2}{|c|}{37} \\
\hline
\end{tabular}

It can be seen that for adults the distrubution differs significantly from the random $\left(\mathrm{X}_{3}^{2}=22\right.$. $\mathrm{P}=<0$.000I). In infants the distribution is as predicted and in children it is intermediate to that in adults and in infants.

If, as has been suggested, blood dissemination occurs from the site of entry early in the disease, it would be expected that the distribution of first lesions would be random. If such were the case one would expect all age groups to show this random distribution, but in the above data this is true of infants and possibly of children. These results are more compatable with siting of the first lesion by some non-random process which affects the whole body to the same extent in infants, but on reaching maturity is more limited in its extent. The figures show a striking deficiency in lesions on the trunk, buttocks and 
thighs in the adult group, and it has becn observed that these are the parts of the body that are covered by clothing in this part of India. The cxcess of lesions found in the limbs is also found in the head and neck if the area covered by hair is excluded. Infants are completely unclothed and during the early years are handled to a great extent by their mothers, and this fits the observed random distribution of lesions in the infant group.

Our series showed no difference in the distribution of lesions in the two hands. (Table 2.).

TABLE II

First lesion on hand or forearm

\begin{tabular}{cc}
\hline Right & Left \\
24 & 28 \\
\end{tabular}

We would therefore suggest that these figures support the hypothesis of entry through the skin, mediated by person to person contact or by minor trauma.

We should like to thank the medical staff of Karigiri, the Christian Medical Ciollege, Vcllore and Vadathorasalor who allowed us to make use of their notes, the members of the MedicoSociological Expedition and the many others in England and India who made this work possible.

This work was supported by grants from the Medical Research Council, the British Leprosy Relief Association and The Leprosy Mission.

\section{REFERENCES}

BERKow, S.G. (1924). A method of estimating the extensiveness of lesions, burns and scalds, based on surface area proportions. Arch. Surg. Lond., 18, I 38.

Spickett, s. G. (1963). Letter to the Editor. Leprosy Review, 34, I $54^{-1} 5^{6 .}$

weddell, G. \& PAlmer, elizabeth (1963). The pathogenesis of leprosy: an experimental approach. Leprosy Review, 34, 57-6I.

WEDDEll G., PAlMer, elizABeth and REes, R. J. W. ( $\left.196_{3}\right)$. I.etter to the Editor. Leprosy Review, 34, I 56-1 58 . 